\title{
ESCO: A Bridge between Labour Market and Education Market
}

\author{
Cristina-Vasilica ICOCIU ${ }^{1}$, Nicolae POSTĂVARU ${ }^{2 *}$ Tiberiu Gabriel DOBRESCU $^{3}$ and Cătălin- \\ Ionuț SILVESTRU ${ }^{4}$ \\ ${ }^{1}$ Universitatea Politehnica din București, Bucharest, Romania \\ ${ }^{2}$ Universitatea Tehnică de Construcții, Bucharest, Romania \\ ${ }^{3}$ Universitatea Politehnica din București, Bucharest, Romania \\ ${ }^{4}$ Academia de Studii Economice, Bucharest, Romania
}

\begin{abstract}
This article addresses, analyses and offers a solution for the ESCO skills/competence hierarchy, based on the taxonomic system of ISCO-08 and ISCED 2013, as well as on the model of the American National Academy of Engineering. The solution is original and belongs to the authors and it can help universities create study programs towards the European desire of the third decade: recognition for all. This would be a big step to the second European desire of the higher education graduates: mobility for all. Through the proposed solution, a connection will be made between the skills and tasks assigned to the job and the level of qualification, thus linking education with the requirements of the labour market and transforming ESCO into the bridge connecting the international standards ISCO and ISCED, by EQF level of qualification. The authors, through their activity, have been interested in this respect for several years and wish that the solution found be proposed to the ESCO Group and promoted at European level. It will be improved and perfected by cooperation projects establishing the skills hierarchies as stated herein. This presentation is new to the field of education and to the relation labour market - education market and it is based on analysis and statistical studies in relevant literature, as resulted from the first part of the article.
\end{abstract}

Keywords: ESCO, ISCO, ISCED, learning outcomes, skills, hierarchy 


\section{Introduction}

\subsection{Europe today}

Today's Europe is different from yesterday's Europe and, of course, from tomorrow's Europe. Today we are facing new European parliamentary parties, unemployment, higher education graduates working below their level of qualification, aging population and its balancing with unskilled immigrants. Today's Europe does not have resources comparable to the United States (USA), Russia, China or South America, nor the military force it would wish for. Today's Europe has a hard time collecting its taxes, with budget cutbacks; in many countries, taxes are not yet directly related to income or to the level of qualification and education. Today's Europe is multicultural, with a high standard of living, with traditions and history but also with the desire not to remain behind.

In this context, in the last 5-10 years there has been more and more talk about a closer connection between education and labour market requirements, in the sense that the former responds to the increasingly dynamic and technical needs of the latter. The role of transversal skills has increased in this context, as a minimum necessity for integration into work and society.

The dynamics of technology development, robotization and automation have led to the re-evaluation of the continuous adult training, which must adapt to the needs of the increasingly mobile market. 5G technology is already here, but not as a positive sign for humanity and traditions, but in the opinion of many, as a pressure on individual freedoms and privacy.

\subsection{Europe of knowledge - universities and knowledge society vs. universities and the labour} market

The concept of "knowledge society" anticipated by the American sociologist Daniel Bell [1], [2] and [3] as representative for the post-industrial society marks a stage in the historical evolution of human civilization, being the one gradually replacing the industrial society.

The widespread use and at low cost of information technology generates, on the one hand, the facilitation of communication at a general level and, on the other hand, new challenges caused by the information overload which, in turn, is accompanied by the need to create new forms of regulation.

The primary feature of the postindustrial society considered "service-based economy" and subsequently it was confirmed that, in reality, the majority of workers were engaged in the creation, processing and distribution of information in the sphere of services. Therefore, the postindustrial society is an information society, within which the functional professions (programmers, managers, economists, lawyers, teachers, doctors, bank officials, social insurance agents, marketing specialists, psychosocial assistance, public relations, etc.) reached through higher education are predominant in relation to those directly linked to production.

The transition from the information society, with an information-based economy, to the knowledge society, based on knowledge, generates major consequences, both cultural and pedagogical through: globalization of education, boosting competition between universities, investment in education and research.

It is well known that any process of social change from the past to the present has been based on progress in knowledge, but the novelty in the knowledge society is given, on the one hand, by the speed with which knowledge is renewed, the fact that its volume doubles every five years and, on the other hand, by its nature, by the driving force that determines the social, economic and cultural changes that goes beyond the world of information technologies.

The speed at which information and communication technologies (ICTs) are introduced, disseminated and used is the most relevant aspect of the knowledge society. Behind the speed, in reality, there are 
many transformations on the specific components of the industrial society that should not be omitted and, in addition, the appropriate correlation between the evolution of ICT and the other components of the knowledge society is required.

Anthony Giddens [4] considers that ICT has contributed to the dissemination of Western culture worldwide, in the form of the values of democracy and market economy. He states that modern institutions differ from all previous forms of social order only "by their dynamism, by the extent to which they undermine traditional habits and customs and by their global impact."

Peter F. Drucker [5] "the founder of modern management" and consultant in educational management, stated in 1993: "The one thing we can be sure of is that the world that will emerge from the present rearrangement of values, of beliefs, of social and economic structures, of political concepts and systems, indeed of world views, will be different from what anyone today imagines. In some areas and especially in society and its structure - basic shifts have, however, already happened. That the new society will be both a non-socialist and a post-capitalist society is practically certain. And it is certain also that its primary resource will be knowledge."

In the knowledge society "information is power", according to the famous saying by Francis Bacon, "knowledge is power", in the most general sense, regardless of its nature, and the acquisition, use and exploitation of information are the basic pillars of this society. Information represents a valuable commodity, the value being given by its potential to be transformed into knowledge.

Knowledge is an essential component of the modern economy, an element of organizational nature based on which we organize our social reality in relation to the knowledge we have and at the same time it constitutes the vein of social power, which comes after other sources that have marked the development of human society - violence (force) and wealth (money).

"Knowledge is a fluid mix of framed experience, values, contextual information, and expert insight that provides a framework for evaluating and incorporating new experiences and information. It originates and is applied in the minds of knowers. In organizations, it often becomes embedded not only in documents or repositories but also in organizational routines, processes, practices, and norms" [6]

Education, as a concept, starting from the etymological meaning of the term, from the Latin word "educo" - educate, which means breeding, feeding or caring, can be considered as representing the process of feeding the individual with ideas, in view of raising him from a lower - natural, to a higher cultural state, a process that involves the development of intelligence, affectivity, will, the general capacity of knowing and transforming of the world, as a whole.

The fundamental purpose of education, as an especially social activity, consists of the creation and passing on of a certain life experience to a human subject who is thus engaged in a mechanism of systematic and conscious influence, in accordance with the aims pursued by collective and individual goals and ideals.

There is still a gap between Europe and the USA, especially in terms of attracting and retaining talent. To reduce this gap, the European Union (EU) has firmly committed to supporting further investments in the European education and training system in general, as well as in the area of research and development and information and communication technology, in particular.

The role of universities is to create a Europe based on knowledge, a role that is both a source of opportunities and a source of considerable challenges. European universities generally have fewer assets and financial means than their correspondent institutions in other developed countries, especially the USA.

Consequently, what answer can be given to the question: do the European universities have the capacity to compete with the best universities in the world and to ensure at the same time, a constant level of exellency?

The most important trends of European higher education are oriented to: student-centered learning 
(attention for each student) and interest in quality.

The student-centered education interest is highlighted by increasing the attention for the student's learning, counselling, guidance and mobility needs, but also by the fact that the student becomes a partner in qualitative assessment and in creating its own academic track.

The quality assurance orientation underlines the role of the dialogue between the interested institutions that are representing employers, public authorities, etc and universities, in order to entail responses from higher education both for the requirements of the society in general, as well as for the business environment and for the student. Realizing the dialogue from the employers and other

stakeholders towards the universities, on the one hand, but also from the universities towards society, on the other hand, in order to explain the reasons and the impact of changes from higher education is vital.

\section{Materials and methods}

\subsection{A new educational paradigm}

There has been a paradigm shift in education: the labour market demands and education honors it, in other words, we no longer "produce" what and how much education wants, but what the labour market needs and how much is needed on medium term; this is a marketing rule showing that education has become a market. Moreover, this change demonstrates that the former students have surpassed their teachers due to the technology development and can better anticipate the dynamic future of the society. The new paradigm entails that the market decides also on the content of education.

Below (figure no. 1) there is a brief representation of the new labour - education system, composed of:

- first "package", made of the labour market and its institutions and defined by the NACE activities (the Statistical classification of economic activities in the European Community)

- second "package" is made of the characteristics of work, given by:

- the occupations from the labour market defined by the employers based on tasks and responsibilities

- the skills and competences required to practice the occupation, as a result of education and experience, normally established by the Sectoral Committees

- the level of qualification indicating the organizing capacity, responsibility and autonomy of the individual in relation to the others, as well as his/her capacity to accumulate knowledge and abilities, established by the labour market and the competent authority

- the occupational standards that contain the information mentioned for each occupation as a standard product, in terms of form and presentation, representing in short what the labour market wants at a given moment form a "qualified" person and how a person becomes as such.

A developed country has detailed occupational standards for all occupations from the national economy and updates them every 5 years the latest, in order to keep up with the requirements resulted from the technological developments.

- third "package" of the new education is made of:

- $\quad$ education and training (qualification) programmes/ study programmes that need to respond to the requirements of the occupational standards, if the case, the new paradigm does not allow for the teachers to design study/ qualification programmes as they wish or by academic autonomy, if they are not based on the request from the labour market or a prevision of such.

This is a first major mentality change in the labour-education relation, basically the "commander" changed, the demand dictates the production, which is well known for decades in marketing.

- the education institutions where the education process takes place, consisting of: 


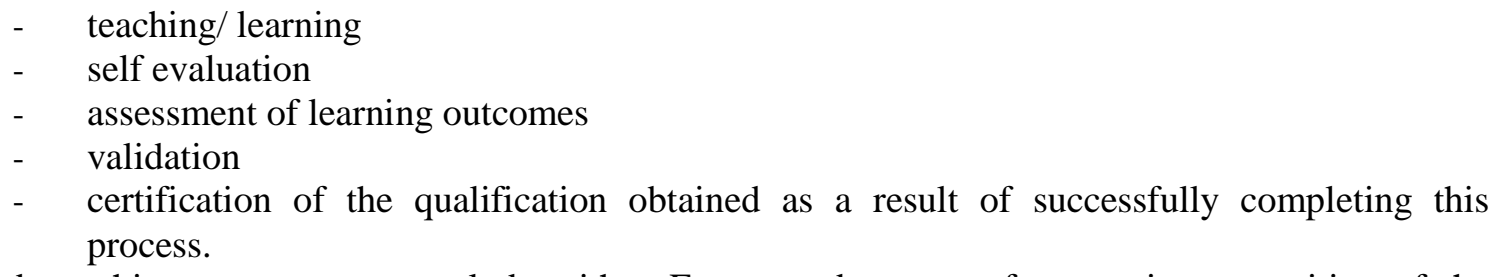
Nowadays, this process must conclude with a Europass document, for a easier recognition of the qualification and the learning outcomes.

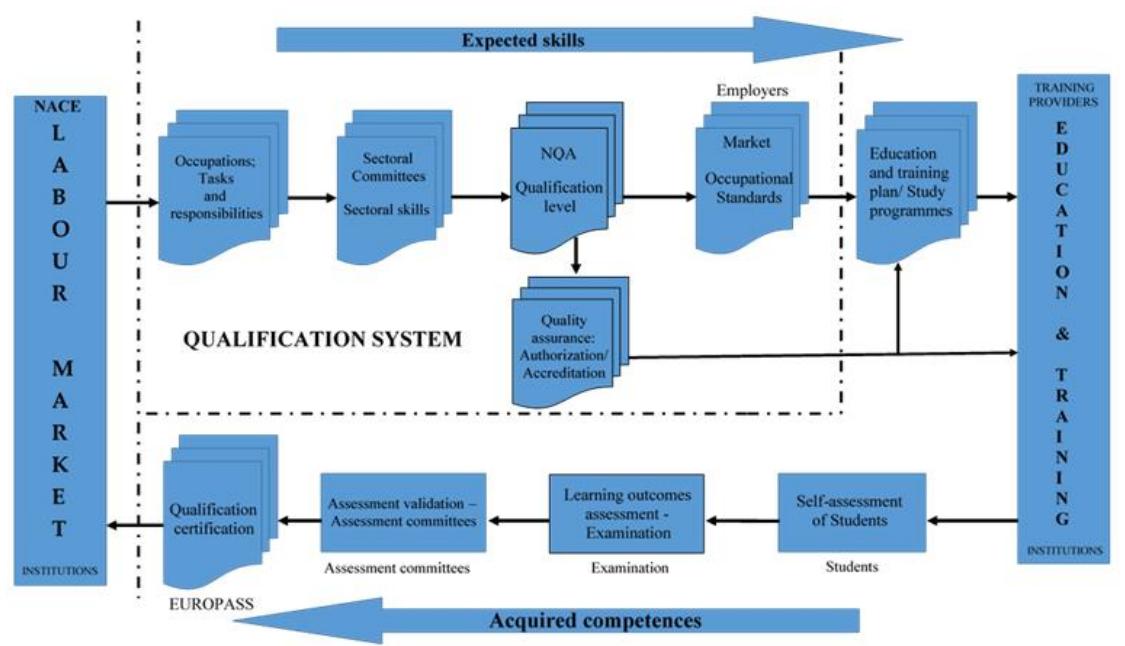

Figure no. 1: Institutional relations in education and vocational training in Romania

Abbreviations and acronyms:

NQA - National Qualifications Authority

NACE - the Statistical classification of economic activities in the European Community

- forth "package" is quality assurance of education system, by:

- institution accreditation, attesting that it is capable to offer education at the promised level

- accreditation of the study/ qualification programme, in compliance with the occupational standards and covering all the European quality requirements requested by the European Standards and Guidelines for Quality Assurance (ESG) and the European ECTS User's Guide.

Without quality, programmes are "in limbo", as any product without a conformity certificate, thus becoming a hazard and a waste of money as well for whoever purchases it.

\subsection{A new monitoring system for vocational education and training}

For all the aspects mentioned in Section 2, monitoring instruments have been created: registers and related standards.

For the institutions from the labour market there is: (i) the Trade Registry (for the commercial entities), (ii) the Register of foundations and associations and (iii) the Register of governmental or mixed institutions.

For occupations there is the ISCO standard (International Standard Classification of Occupations), the most recent version ISCO-08 (published in 2008), based on a taxonomic system [9]. The standard is implemented in all European countries, and not only, up to level 4 of classification, the unit group.

For skills and competences, in Europe, ESCO classification was created (European classification of 
Skills/ Competences, qualifications and Occupations) which shall be further detailed [10].

Each country has registers for occupational standards.

Each country has a national register for qualifications, which, according to the Council Recommendation of May 22, 2017 [11], should have a common format in all European countries, thus becoming a standard. Is comprises the standard field of ISCED (the International Standard Classification of Education) [12], the level of qualification (standard), description of the qualification based on learning outcomes and information related to quality assurance, as well as to the entity issuing the qualification (accredited institution).

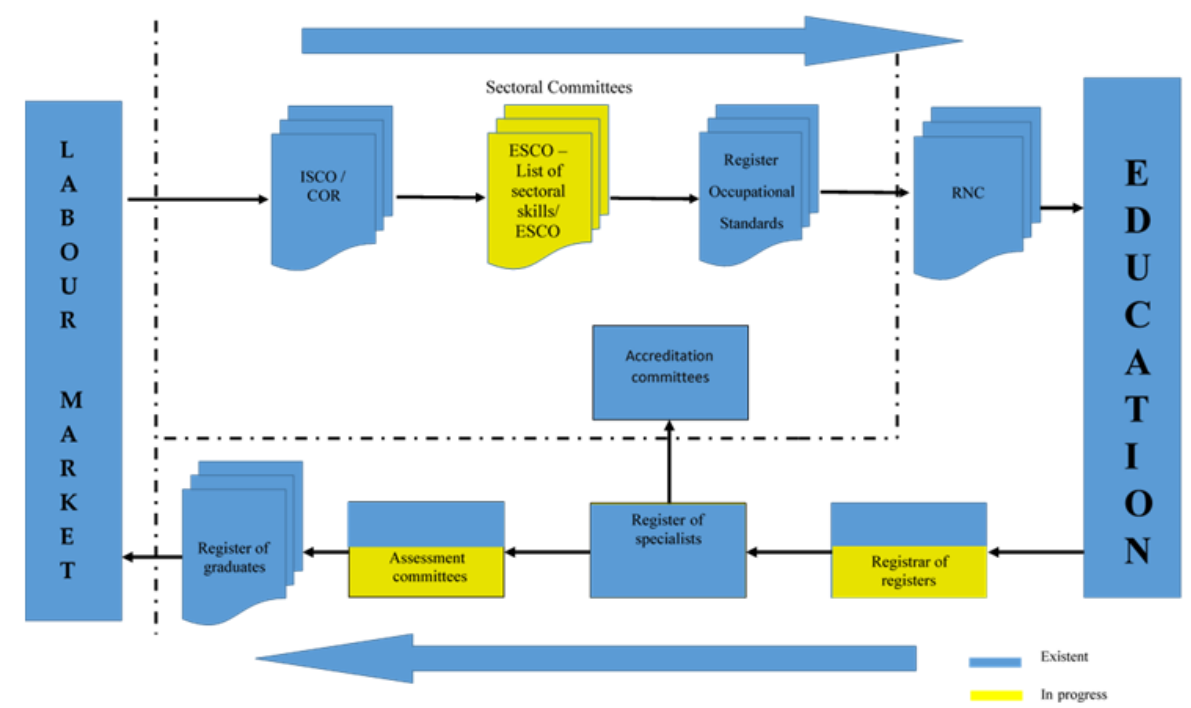

Figure no. 2: The monitoring and information system for vocational education and training and the institutions responsible

\author{
Abbreviations and acronyms: \\ ISCO - International Standard Classification of Occupations \\ COR - Romanian Classification of Occupations \\ ESCO - European classification of Skills/ Competences, qualifications and Occupations \\ RNC - National Register of Qualifications
}

There are also registers with information about those involved in the vocational education and training system. The educational institutions, the accredited ones, are registered. We can talk about the register of those enrolled in the formal education system, but also of the register of graduates from an education system. There are registers of specialists and various commissions that offer degrees and diplomas. Finally, there is also the register of quality assurance institutions and their commissions. The above figure (figure no. 2) summarizes all these registries for monitoring the education and training course at higher or pre-university level. Their role will be relevant when discussing recognition of qualifications and mobility of graduates from one country to another, on the European common market.

This monitoring and information system comprises:

- a system that manages occupations and their framework, for the EU - ISCO-08

- a "manager" of sectoral skills, it should be the professional associations, but there is no uniformity yet in this respect, at European level - ESCO

- a "manager" of occupational standards 
- a "manager" of qualifications - the National Register

- a "manager" for quality, which conducts the audit of the vocational education and training providing institutions

- the register of those who are in training programs

- the register of specialists/ trainers classified on ISCED fields and qualification levels

- a register of graduates

- a register of education and training providers

This transparency of the system offers trust and, if accompanied by an employability register, it would lead to appreciating education at fair value.

\subsection{Standardization - progress, recognition and mobility factor}

It can be said that this market made up of work and education "plays" around some standards that must be implemented so that we can speak of the desiderate of European treaty between countries: "free access to goods and services" [13]. In order to have the desired recognition and mobility, we

must fully and correctly implement:

- ISCO-08 (2008 version), with its definitions and structure and understand that up to the unit group level, 4 digits, we cannot change anything without the agreement of the other international partners who adopted it. The Member States can have specific occupations, but, not so much new unit groups, different from the agreed standard.

- EQF (the European Qualifications Framework) - here Romania is in a good place and has approved the latest version proposed in May 2017 [11], by which learning outcomes were defined in terms of knowledge, skills, responsibility and autonomy of the qualified individual.

- ISCED 2013 - F, the international standard of education that establishes a hierarchy of the fields of study in education up to level three: detailed field. Member States may have new themes / specializations within a detailed field, but less new detailed fields. Detailed fields are unique by name until their amendment is decided and approved. These changes are made by the issuer, UNESCO and approved at international level by representatives of UN member countries, which is why it is an international standard. We must understand that a standard is complied with, not sought to be bypassed or avoided.

- Quality is ensured by including the national specialized institutions in the EQAR registers for higher education (The European Quality Assurance Register for Higher Education) and ECVET for vocational education and training (European credit system for vocational education and training).

- The documents, diplomas and diploma supplements and certificates are already standardized through the Europass portfolio.

Therefore, it can be said, that we are in a circle of "standardization" of education in relation to the labour market, as presented below (figure no. 3). Capitalist society means standards and procedures.

An example in this respect is constituted by the regulated professions, but these go further, respectively up to the standardization of the study programmes: disciplines, duration, practical training, the level of equipment / laboratories, the minimum level of teacher qualification and the teaching mode - only in this way we can talk about the recognition of qualifications, in this example about the automatic recognition of qualifications.

If we take into account the last messages of the representatives of the European Higher Education Area, which are aiming for recognition for all for 2030, precisely the recognition of qualifications, we understand that in the coming years, according to the model of the regulated professions, the current list will be expanded much more for other professions as well. 
The question arises whether standardization is good? We take into account the economic experience of the past 30 years, which has proved that, if we cannot keep up with the market standards, the products and the related companies are automatically eliminated from the market and terminated; we understand the "power of standards" in the capitalist world.

A standard is a higher requirement that you are affiliated with, or if not, in time, you disappear. This is the rule of the global market, if you cannot offer a product at the required standard, someone else

comes and takes you out of the market.

This danger is also valid for the vocational education and training system, western universities will come to the east, those from the USA or China to Europe or Africa, Australia.

The good ones raise the standards with a clear purpose: to conquer the market, and the European education market is a multi-billion euro market.

We want Romanian market to be prepared to adopt the standards, to adhere to them, to participate in their accomplishment, if it can, under no circumstances to avoid them, because the results would be disastrous on long term for higher and technical education.

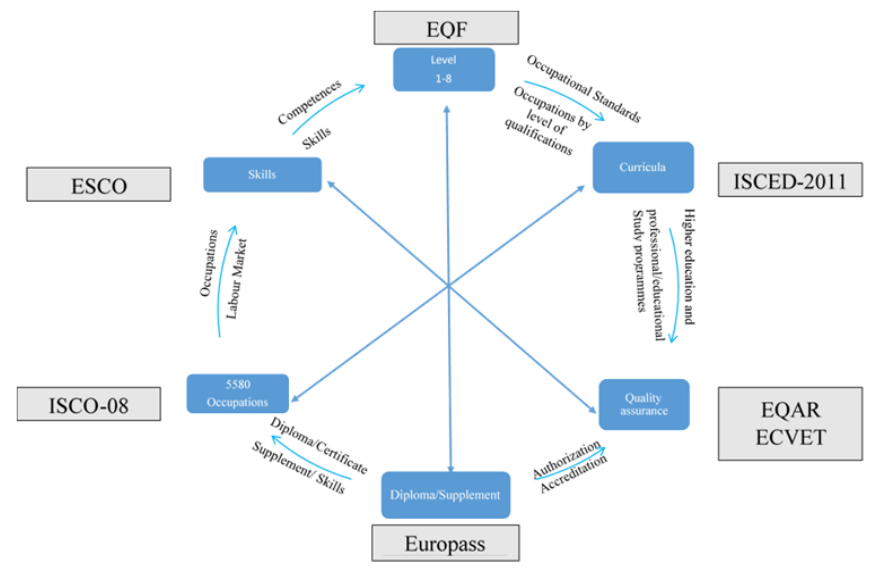

Figure no. 3: Standardization of education and training in relation to the labour market

\subsection{Taxonomy, common element}

What often connects these standards, through unseen threads, is taxonomy, that is, the system by which an element decomposes into others and each in turn into others and so on, a system based on which is created the world which decomposes to its component particles, but which can also come together in reverse and give the original as a whole, meaning it is a more physical, than chemical, decomposition.

When analyzing ISCO-08, one can notice that it can be broken down into components called groups: 9 major groups, then major subgroups, minor and unit groups, which are internationally recognized (figure no. 4).

Each group is characterized by a number and its tasks and responsibilities, more general to the "higher" groups and more specific to the "lower" groups, the closer we are to the occupation. Finally, it can be stated that an occupation is a sum of tasks and responsibilities given by each figure / group that it is comprised of. 


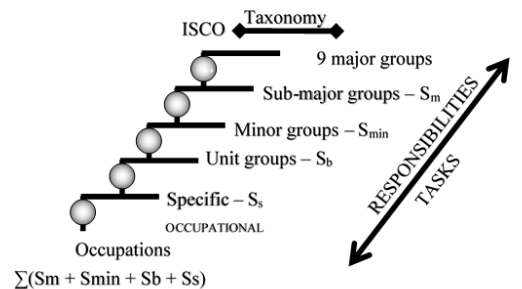

Figure no. 4: Organization of ISCO Classification, seen with respect to tasks/responsibilities

If we analyze ISCED - 2013, we notice the same taxonomic system organized by fields of study designated and internationally recognized as: broad, narrow, detailed fields and with subjects for specializations that represent areas of national interest (figure no. 5).

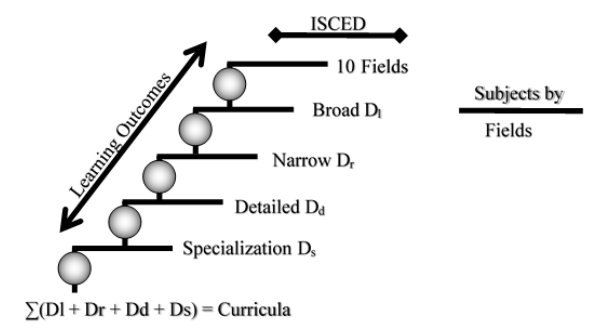

Figure no. 5: Taxonomic organization of ISCED

If these fields also have disciplines assigned (see the regulated professions above), it can be said that

for any specialization we will have a sum of common disciplines, from the three fields that are common, up to the level of specialization; the curriculum becomes a sum of disciplines that represent each field and, at the same time, for example, connects specializations from the same detailed field. It is a fabric of domains and disciplines that gives the beauty of the surrounding reality, of the real nature.

If one compares everything with a house (figure no. 6), it can be said that the responsibilities and tasks specific to a major subgroup characterize the ISCED broad field and lead to main disciplines, which represent the land on which the edifice is erected - the individual's personal, home education.

In the new European construction, these disciplines are those that lead to key competences, on the one hand and/ or to the transversal ones, on the other hand.

These should help the individual understand the surrounding world, become better fixed in place and personally develop.

Just like the land, skills become more and more important on long term for one's career. 


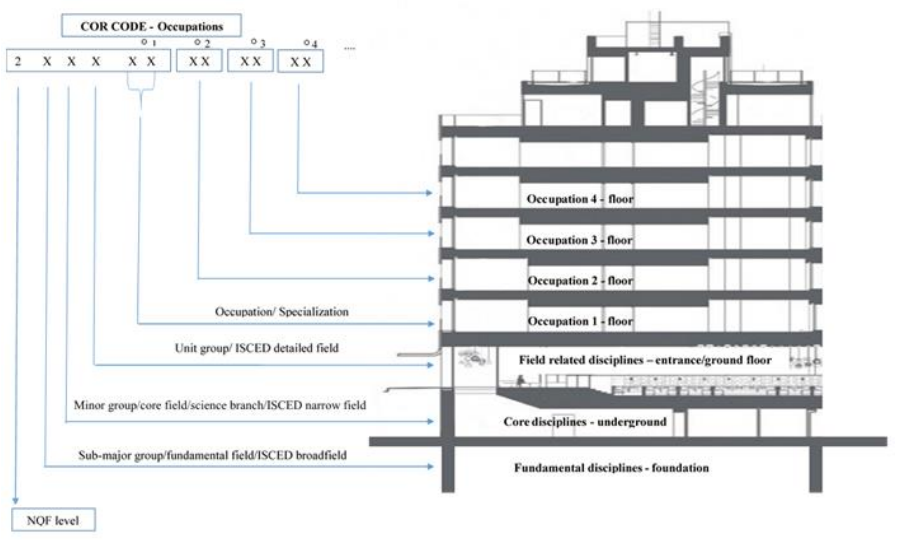

Figure no. 6: The relation labour-education seen through occupations-disciplines

Similarly, the tasks and duties of the minor group lead to the ISCED narrow field, which can be the core disciplines or the foundation of the edifice, what the individual wants to do, learn and work.

Like any foundation, each individual can designed it, but the land he builds on must be carefully considered. Poor land means a lot of foundation work to make it solid and vice versa.

The fundamental and core disciplines support the future construction, they give the stability and the sustainability of the professional career.

If you choose a way in your life, a "land" and you build a "foundation" it is difficult to change them, that is why a person's skills, nature, soil must be well chosen, evaluated, advised and identified.

The authors recommend and argue that the fundamental and core (basic) disciplines must represent

about $50 \%$ of the professional training of the individual.

The tasks and responsibilities of the unit group lead to the fields related disciplines and the ISCED detailed field. On the same land and the same foundation, several types of solid "constructions" can be built, these represent the occupations from the chosen unit group, possible to practice in the course of one's career.

On the same foundation, the basic fields can be changed, they can be alternated in life, as they say "individuals can make variations on the same theme or foundation".

On top of these, the specialized disciplines in the field of specialization / ISCED subjects are added, any sum of such disciplines can lead to one occupation from ISCO unit group.

It is similar to the grafting on the same stalk with several varieties; if it were a joint and solid stalk, it can support all of them, each with its own taste or smell.

Also, the individual can change the unit group when the foundation supports it, through ongoing training that should help him grow and expand on a personal and professional level.

\subsection{The European skills and competences system - ESCO}

So far, things would seem organized based on the two international standards (ISCO-08, ISCED), but as previously shown (figure no. 3), the system also includes one element: skills. These are at the basis of learning outcomes. The essence of today's vocational education and training is represented by learning outcomes, or what an individual can actually do with the knowledge and abilities, skills acquired in the education and training process.

Is the European ESCO system a taxonomic system?

Could it be? Can we prove it? The authors think so.

The following figure (figure no. 7), shows such a possible system created by ranking the competences 
according to the model presented in the previous figure (figure no. 6), respectively core, fundamental, field related and specific skills.

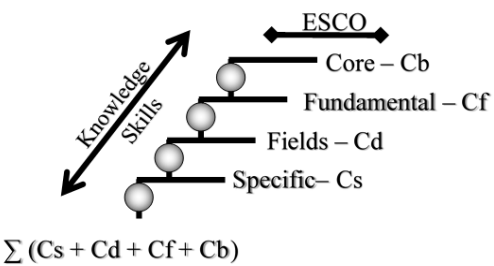

Figure no. 7: Taxonomic organization of ESCO

This would lead to the idea that the one who practices an occupation has different types of skills and competences, some specific to the occupation and others that are useful for other occupations or to solve the problems in the company or within the team, what we call personal skills.

Through school we should acquire the key or, more recently, the academic competences. Part of these competences are the transversal ones, so demanded by the labor market in the new context of technology and of the dynamics of the work and the related environment.

Thus, it can be said that each individual has his or her own life course, in which he/ she chooses when to move from one level of qualification to another, 6/7/8 NQF (figure no. 8, section A), or chooses different durations of time / moments in life for: qualification, retraining, specialization, non-formal learning (figure no. 8 sections B, C and D). Here comes in the freedom of everyone to choose the land, the foundation, the road, the career, the future.

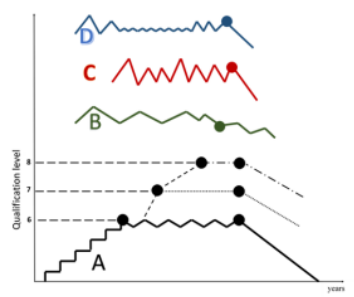

Figure no. 8: Life cycle

Using the following image (figure no. 9) the authors wish to make it understood there must be correlation between occupations, skills/competences, qualifications and levels of qualification, a link that has long been missing and which is now given by ESCO which becomes the bridge between the labor market, represented by: occupations/ duties/ tasks/ qualifications and the education market, represented by qualification levels/ learning outcomes, curriculum, credits, quality assurance.

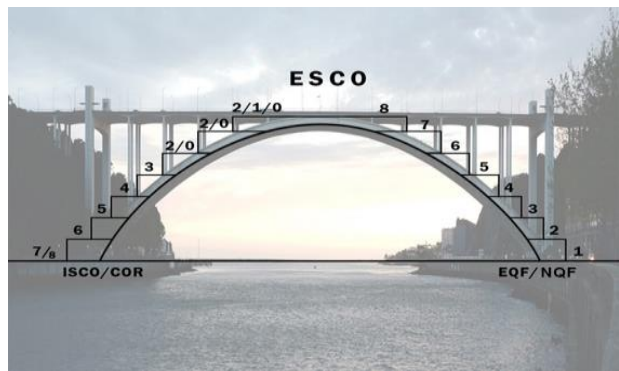

Figure no. 9: ESCO - The bridge between labour market and education market

\section{Discussion}




\subsection{Construction of study programmes}

In the USA, the National Academy for Engineering developed in 2015 a skills model [14] as a basis for designing international programs (figure no. 10). It was concluded that tomorrow's engineer needs the following skills:

- core: personal and academic (level 1 and 2),

- transversal or specific for the workplace (level 3),

- technical, general (level 4),

- fundamental and field related: specified by each industry separately (level 5),

- $\quad$ specific: occupational and managerial.

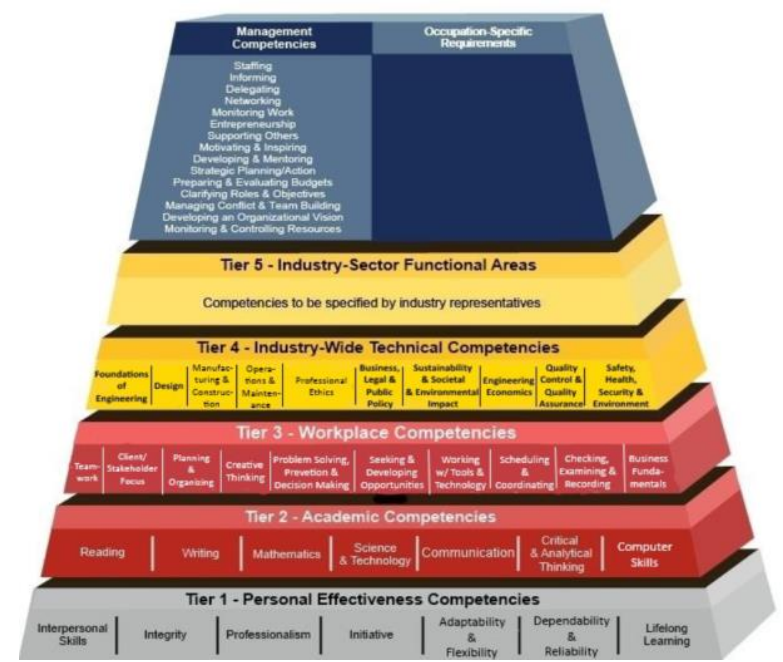

Figure no. 10: USA skills model (source: ETAUSDL, 2015)

In comparison with this system, the authors propose a European system focused on ISCO tasks and responsibilities, on ISCED study fields (figure no. 11) and the hierarchy of skills/competences according to the taxonomic model (figure no. 7).

In the end, it will also be in the shape of a pyramid, but built according to another calculation model based on the layout from the following figure (figure no. 11).

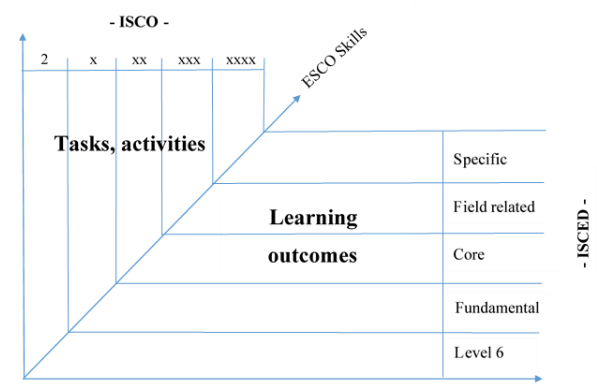

Figure no. 11: Example of skills/competences hierarchy

In this proposed system, ISCO major group indicates the level of NQF qualification, the rest falling under the taxonomic systems, as previously presented (figures no. 4, 5, and 7).

The authors propose a way of designing the study/ qualification programmes that permanently respond to the demands of the labor market, expressed through tasks and responsibilities and concluded by upto-date skills and concrete learning outcomes, beneficial to the individual. 


\section{2nd International Conference on Advanced Research in Teaching and Education}

Thus, a pyramidal system, similar to the American one, is created, but according to the international standards model from the table below (table no. 1), where an example of engineering field of study is presented. One can notice that it is the same pyramid, only that we have to insert skills/ competences from ESCO, ranked by qualification levels and ISCO groups.

This is the point where one can talk about the hierarchy of skills/ competences, according to ISCO and ISCED, and then about the associated learning outcomes.

To make the work easier the authors propose in the next table (table no. 2) a two-part system:

- a common part, at European level, for the development of European programs for core (basic)/ fundamental/ field related levels and

- a specific part, through national programmes, for the development of specific fields/ disciplines.

Thus, ESCO becomes an instrument as it was initially presented: of establishing a minimum European skills/ competences sets necessary for the recognition of qualifications (about 70- 75\% of those an applicant has in its portfolio at employment), which are locally complemented by another set given by the specifics of the qualifications in the respective region and university/ training supplier (about 25$30 \%)$.

Thus, one can talk about internationalization, mobility for all, digitization, innovation, and support of young people's employability in the European common labor market. 
Table no. 1: The layout for designing study programmes based on ISCO and ISCED - example ISCED 07

\begin{tabular}{|c|c|c|c|c|c|c|c|c|}
\hline $18 c 0$ & $\begin{array}{l}\text { TRSKS AND } \\
\text { RESPONSIBI } \\
\text { LTIES }\end{array}$ & $\begin{array}{l}\text { SKIIIS } \\
\text { COMPETENCES } \\
\text { Gien by the employer or } \\
\text { ESCO }\end{array}$ & ISCED & $\begin{array}{l}\text { LEARNING OUTCOMES } \\
\text { Far kevel } 6: 7\end{array}$ & \multicolumn{4}{|c|}{$\begin{array}{l}\text { BUILDING } \\
\text { Study programuse }\end{array}$} \\
\hline OCCUPATIONS & 章 & 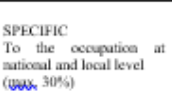 & SPECIAL.TY FIELD & 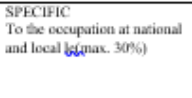 & $\uparrow$ & & & \\
\hline $\begin{array}{l}\text { UNIT GROUP } \\
2141.2144: 2151 \text { - } \\
2153 \\
\text { Field } \\
\text { Fagbicering } \\
\text { Professionals }\end{array}$ & \multirow{3}{*}{ 焉 } & $\begin{array}{l}\text { FIFID RELATED } \\
\text { Cammon for the field }\end{array}$ & $\begin{array}{l}\text { DETAllFD FIFLD } \\
\text { 0711-07160 0721-0726 } \\
0731-073210788\end{array}$ & $\begin{array}{l}\text { FIFLD RFLATED } \\
\text { Cammen for the field of } \\
\text { stady }\end{array}$ & & 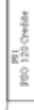 & $\begin{array}{c}2 \\
\frac{1}{2} \\
\frac{2}{2} \\
8\end{array}$ & $\frac{1}{8}$ \\
\hline $\begin{array}{l}\text { MINOR GROUP } \\
214 / 215 \\
\text { Engisering } \\
\text { Professional }\end{array}$ & & $\begin{array}{l}\text { CORE } \\
\text { Cammon for engixees }\end{array}$ & $\begin{array}{l}\text { NARROW FFILD } \\
\text { OT1.072073:078 }\end{array}$ & $\begin{array}{l}\text { CORE } \\
\text { Cammou for engixeex }\end{array}$ & & \multirow{2}{*}{\multicolumn{3}{|c|}{$\begin{array}{l}\text { Frameured } \\
\text { progranume } \\
\text { by ISCED } \\
\text { field }\end{array}$}} \\
\hline 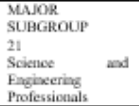 & & $\begin{array}{l}\text { FUNDAMENTAL } \\
\text { Common far sciesce and } \\
\text { eagineess }\end{array}$ & $\begin{array}{l}\text { BROAD FIFLD } \\
0 \%\end{array}$ & $\begin{array}{l}\text { FUNDAMENTAL. } \\
\text { Cammon for science and } \\
\text { eagineens }\end{array}$ & & & & \\
\hline
\end{tabular}

PC - FRAMEWORK PROGRAMME - international competences from ESCO and similar Learning Outcomes

PSO - OCCUPATIONS SPECIFIC FOR THE PROGRAMME - competences set by the national (10\%) and regional (20\%) employers

Table no. 2: The structure for designing study programmes based on skills/ competences

\begin{tabular}{|c|c|c|c|c|c|c|c|c|c|}
\hline $\begin{array}{l}\text { COR } \\
\text { Code } \\
\text { Gr. } 2 \\
\end{array}$ & $\begin{array}{l}\text { COR } \\
\text { structure }\end{array}$ & NQF & $\begin{array}{l}\text { Tasks and responsibilities } \\
\text { ISCO/COR }\end{array}$ & ESCO skills / competences & $\begin{array}{l}\text { Learning } \\
\text { Outcomes }\end{array}$ & ISCED field & Disciplines & $\begin{array}{l}\text { Percentage } \\
\% \text { min. }\end{array}$ & $\begin{array}{l}\text { ECTS } \\
240 / \\
180 \\
\end{array}$ \\
\hline \multirow[t]{2}{*}{$2 \mathrm{xxxxx}$} & \multirow[t]{2}{*}{ Occupations } & \multirow[t]{2}{*}{6} & According to the employers & $\begin{array}{l}\text {-transversal } \\
- \text { at the universities discretion } \\
\text { (national/ local) }\end{array}$ & $\begin{array}{l}\text {-transversal } \\
\text {-professional }\end{array}$ & Narrow & $\begin{array}{l}\text { Specific for the } \\
\text { workplace }\end{array}$ & $\begin{array}{l}15 \% \\
10 \%\end{array}$ & $\begin{array}{l}36 / 24 \\
24 / 18\end{array}$ \\
\hline & & & $\begin{array}{l}\text { According to ISCO/COR and } \\
\text { the employers }\end{array}$ & Specific ESCO & Specific & Specialization & $\begin{array}{l}\text { Professional/ } \\
\text { specialized }\end{array}$ & $20-25 \%$ & $48 / 36$ \\
\hline $2 \mathrm{xxx}$ & Unit Gropu & 6 & According to ISCO & Field related & Field related & $\begin{array}{l}\text { Detailed- } \\
\text { oxxx }\end{array}$ & Field related & $20 \%$ & $48 / 36$ \\
\hline $2 \mathrm{xx}$ & Minor Group & 6 & According to ISCO & Core & Core & Narrow-oxx & Core & $20 \%$ & $48 / 36$ \\
\hline $2 \mathrm{x}$ & $\begin{array}{l}\text { Major } \\
\text { Subgroup }\end{array}$ & 6 & According to ISCO & Fundamental & Fundamental & Broad-ox & Fundamental & $5 \%$ & $24 / 18$ \\
\hline 2 & Major Group & \multicolumn{8}{|c|}{$\begin{array}{l}\text { - Major Group 2: tasks, duties, autonomy, responsibility, level } 6 \text { competences/ First Degree - } 5 \% \\
\text { - Level } 5 \text { learning outcomes existing and obtained by Baccalaureate }\end{array}$} \\
\hline
\end{tabular}

In Romania: Year I+II= 50\% - 20 DISCIPLINES: fundamental, core, field related, transversal, at the university's discretion Year III+IV = 50\% - DISCIPLINEA: field related, specialized, transversal, at the university's discretion

Example of fundemantal disciplines: major subgroup 21 Science and Engineering Professionals: physics and earth science, life science, engineering professions, mathematicians and statisticians, architects and designers - disciplines that are common for all: mathematics, physics, $\Sigma$ optionals 
The new system for Romania is presented in the following figure (figure no. 12), and includes all the relationships and institutions mentioned in Section 2, responsible for each activity.

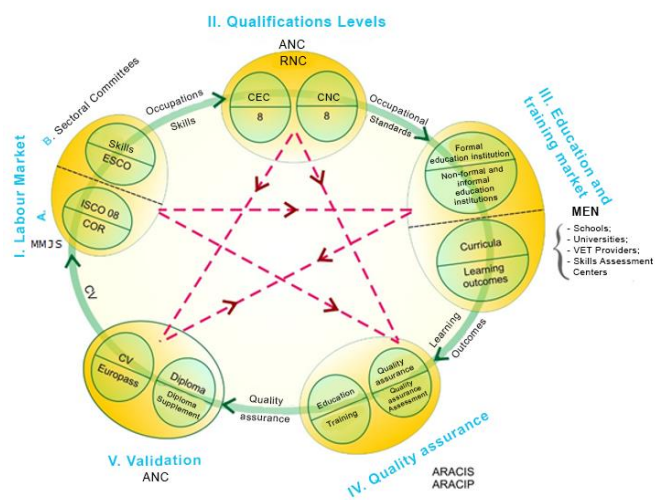

Figure no. 12: Education-labour market diagram

Abbreviations and acronyms:

ANC - the National Qualifications Authority; MMJS - the Ministry of Labour and Social Justice; MEN - the Ministry of National Education; ARACIS - the Romanian Agency for Quality Assurance in Higher Education; ARACIP - the Romanian Agency for Quality Assurance in Preuninersitary Education; RNC - the National Qualifications Register; CEC - the European Qualifications Framework; CNC - the National Qualifications Framework; COR - the Romanian Classification of Occupations

What are we missing today? The hierarchy of ESCO skills/ competences and the curriculum designed based on such skills, hierarchically, in pyramid form, starting with the common skills which bring us closer to everyone in Europe and then moving to the specific ones, depending on the country or region, industry, activity, qualification level.

The labour market can be correlated with the education market if ESCO undertakes its initial tasks and is further supported at European and local level.

\subsection{The future of higher education}

Motto: "Not every storm comes to destroy your life, some come to clear your way", Priest Constantin Galeriu

Many people question how higher education will be like after 2025-2030.

In the spirit of those presented and mentioned by the World Economic Forum, that higher education is one-step ahead of school in terms of demand; it is shaped to be organized according to th following system:

- A short-term general higher education (2-3 years) organized on ISCED broad fields. In the future, due to the changes in the economy and the speed they occur, it will be difficult for a young person to wish for a narrow specialization because, until graduation, the student may not know if that specialization exists anymore.

This short education will include:

A. On the one hand, basic - transversal competences and related disciplines: for example, the 10 soft skills [15]:

1. Cognitive Flexibility - The ability to generate or use different sets of rules for combining or grouping t10. Cognitive

2. Complex Problem Solving - Developed capacities used to solve novel, ill-defined problems in complex, real-world settings.

3. Coordinating with Others - Adjusting actions in relation to others' actions.

4. Creativity - The ability to come up with unusual or clever ideas about a given topic or situation, or to develop creative ways to solve a problem. 
5. Critical Thinking - Using logic and reasoning to identify the strengths and weaknesses of alternative solutions, conclusions or approaches to problems.

6. Emotional Intelligence - Being aware of others' reactions and understanding why they react as they do.

7. Judgement and Decision Making - Considering the relative costs and benefits of potential actions to choose the most appropriate one.

8. Negotiation - Bringing others together and trying to reconcile differences.

9. People Management - Motivating, developing and directing people as they work, identifying the best people for the job.

10. Service Orientation - Actively looking for ways to help people

These are similar to the American system presented for engineers, based on personal, academic and workplace skills and competences.

They will be generalized for any graduate and differentiated by qualification levels.

B. Fundamental competences as a result of successfully completing the fundamental disciplines, each identified for the 10 ISCED fields, established in accordance with the employers, but with a reduced amending time rate, for example, 1:10/15 years.

C. After graduation, the individual will receive a certificate stating his fundamental training and the chosen field; with the exception of the regulated professions.

On this basis, and foundation a new career through school will be built, depending on each person's skills and the market requirements.

The short cycle graduate will have to choose between several fields, to build on the fundamental one, through specialized study programs.

- Specialized higher education

After the short cycle, there will be a training/ specialization period lasting 1-2 years, in the desired field, in accordance with the fundamental field, organized in two stages:

C1. Field related training, with the duration not exceeding 60 credits.

In time, this can be changed/ updated at intervals of 5 years. The individual will be able to change his field of activity and/or will be retraining several times in his life, depending on skills, market, desires, and other personal requirements. Through recognition, this retraining period will be reduced to maybe 30 ECTS credits or less.

This system is especially useful for young people, with an attraction for a fundamental field, but not knowing what narrow field to choose, and "fumbling" through society until they find the one they like. Along with appropriate practice, this will usually take the shape of formal training.

\section{C2. Specialized training}

The young graduate, who holds the 150-180 ECTS credits, will be able to choose between specialized study programmes for the desired specialization.

Specializing courses will be attended at the faculty level in a formal or post-university system of continuous training, through short-term specializing courses, 15-30 credits; this is shown in short in the following figure (figure no. 13).

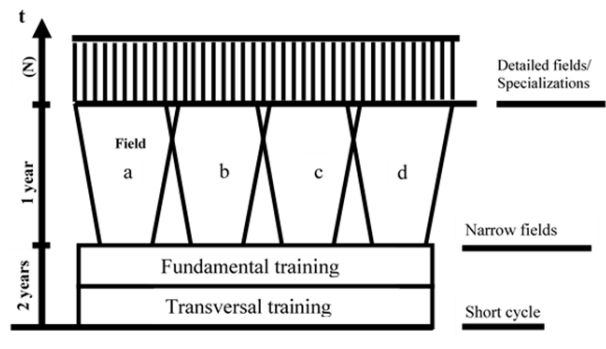

Figure no. 13: Future of training

The duration of these programs can be reduced in time, by recognizing competences and learning 
outcomes acquired previously or through experience.

The training will no longer be for specialized occupations, but for specialized learning outcomes (World Economic Forum 2016), which will have a wider utility. The role of experience will increase decisively at the expense of specialized theoretical training.

Based on those presented herein, the authors' model on the hierarchy of competences and the development of higher education study programmes - the pyramid of vocational education and training is shown below (figure no. 14). It is also a response to the American model.

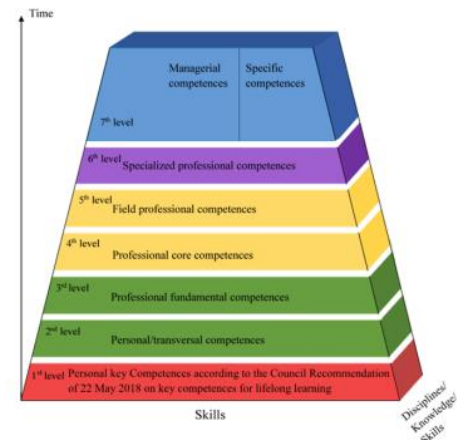

Figure no. 14: The model proposed for the ESCO competences hierarchy

\section{Conclusions}

Education will adjust to technology; knowing how to think, search, and create will be tomorrow's requirements and goals.

The computer will replace bureaucracy.

Information will be available in the cloud, it will be sufficient for everything we want, but we will need to know how to access it.

The care for people, environment, and resources will increase and we pray that violence will be replaced by communication.

That is why we will have to understand the role of personal/ transversal skills and competences taught from an early age in society, according to the level of education and understanding of each person.

Many will ask themselves what skills God gave them, and will pray to find the way God set for them, which will be the hardest and most valuable thing in the future.

NEGOTIATION, UNDERSTANDING, HARMONY MUST BECOME THE PURPOSES OF TOMORROW'S EDUCATION. 


\section{References}

[1] D. Bell (1967) Notes on the Post Industrial Society, I; II, în The Public Interest

[2] D. Bell (1973) The Coming of Post-Industrial Society, Ed: Basic Books, ISBN-13: 978-0465097135, ISBN-10: 0465097138

[3] D. Bell (1976) Welcome to the Postindustrial Society, în Physics Today (febr. 1976)

[4] A. Giddens (1991) Modernity and Self-Identity: Self and Society in the Late Modern Age, Stanford U niversity Press, ISBN: 9780804719445

[5] P. F. Drucker (1993), Post-capitalist society, Butterworth-Heinemann Ltd

[6] T.H. Davenport, \& L. Prusak, (1998) Working Knowledge: How Organizations Manage What They Know. Harvard Business School Press, Boston

[7] European Standards and Guidelines for Quality Assurance in the European Higher Education Area, 2009

[8] ECTS User's Guide, 2015

[9] International Standard Classification of Occupations, 2008

[10] ESCO - https://ec.europa.eu/esco/portal

[11] COUNCIL RECOMMENDATION of 22 May 2017on the European Qualifications Framework for lifelong learning and repealing the recommendation of the European Parliament and of the Council of 23 April 2008 on the establishment of the European Qualifications Framework for lifelong learning (2017/C 189/03)

[12] International Standard Classification of Education (ISCED), 2011

[13] Treaty on the Functioning of the European Union, 2012

[14] International Standard Classification of Education: Fields of Education and Training 2013

[15] Employment and Training Administration United States Department of Labor (ETAUSDL) www.doleta.gov - Engineering Competency Model - May 2015

[16] Work Economic Forum (2016) The Future of Jobs: Employment, Skills and Workforce Strategy for the Fourth Industrial Revolution, Link: http://www3.weforum.org/docs/WEF_Future_of_Jobs.pdf 